\title{
THE EFFECT OF APPLICATION BASED ANDROID TO DEVELOP THE KNOWLEDGE OF PLANT IDENTIFICATION FOR BIOLOGY EDUCATION COLLEGE STUDENT
}

\author{
Didi Jaya Santri ${ }^{1 *}$, Susy Amizera ${ }^{2)}$, Nike Anggraini ${ }^{3)}$ \\ University of Sriwijaya \\ dj_santri@unsri.ac.id
}

\begin{abstract}
Plant identification is a process of determining plant species based on classification system by observing either morphological structure or anatomical structure of the plant. The aim of this study for determine the effect of using applications on the ability to identify plants for biology education college students by comparing the identification abilities of students after carrying out plant identification activities using matching plant the characteristic of object methods and application-based android. The research design used the pretest - posttest group design technique with 60 students. Furthermore, data analysis used $N$-gain test to determine the improvement of collage students' abilities and independent sample t-test to determine the effect of the use of application-based android on the ability to identify plants with the prerequisite test for the normality test and homogeneity of the research sample. The results showed that there were differences in the improvement of students' abilities in plant identification activities. The data showed that the increase in knowledge in the treatment class was higher due to the use of application-based android by students. The independent-sample t-test analysis showed the sig value. 0.00 (<0.05). It indicates that there is a significant difference in increasing student knowledge in plant identification activities in classes, where the experimental class shows a better improvement than the control class. Thus, it can be concluded that the use of application-based android affects the ability of plant identification in college students
\end{abstract}

Keywords: plant, identification, application-based android

\section{INTRODUCTION}

Plant identification is a process of determining plant species based on classification system by observing either morphological structure or anatomical structure of the plant. According to Pusat Konservasi Tumbuhan Kebun Raya, The purpose of the identification activity is to facilitate students to recognize plants easier which related to contextual learning (Pusat Konservasi Tumbuhan, 2018)

However, some research results show that the ability to identify plants on collage students is still in the sufficient category and has not been implemented optimally (Fitriani \& Wardianti, 2014); (Nanggala \& Utara, 2020). Plant identification activities generally still use conventional methods. They usually do by asking plant experts, matching the specimens, using identification books and using key determination (Isti et al., 2015); (Suwila, 2015); (Aring et al., 2017). The use of identification techniques by matching plant objects with identification books and using a key determination takes a long time because college students have to match one by one the pictures to the identification book with the observed plant objects.

Along with technological advances, there are several applications that can help the process of plant identification. The use of applications in plant identification activities is preferred based on the aspect of convenience (Prasvita \& Herdiyeni, 2012). One of the applications which is developed for the plant identification process is namely plant net. Based on the results of the study about the use of plant net applications in the identification, it can assist in identification activities in a practical and efficient. Also, it does not spend much time in identification activities (Rifa et al., 2020). Therefore, the 
application based on android can be used to facilitate student for identification activities.

Biology education college students are prospective to be the teacher who will transfer knowledge to students. One of the competencies that must be mastered by them is the ability to identify plants because there are teaching materials in high school that related to the classification system and biodiversity, especially in plants. In addition, mastery of technology needs to be mastered by prospective teachers in accordance in 4.0 learning era. Thus, this research is important to determine the effect of using application-based android on the ability to identify plants for biology education college students

The aim of this study was to determine the effect of using applicationsbased android on the ability to identify plants for biology education college students by comparing the identification abilities of students after carrying out plant identification activities using conventional methods and application-based android.

\section{RESEARCH METHOD}

This research is an experimental research design with the treatment of two groups of students. The first group as a control class will identify the plants using identification techniques by matching plant the characteristic of object and the second group as a treatment class will use an android-based application. The research design used the pretest - posttest group design technique. Furthermore, the researchers do normality and homogeneity tests to obtain information that the data values were normally distributed and homogeneous.

This research was conducted at the Biology Education Study Program, Faculty of Teacher Training and Education, Sriwijaya University. The participants in this study were fourth semester students in the Biology Education Study Program

The data from this study were obtained through quantitative analysis using the analysis of N-Gain and independent-sample t-test with the test equipment using SPSS 20 software. The analysis of the difference test (T-test) was included in the comparative test to compare the averages of the two groups that were tested significantly different. In this study, the T-Test test was used in order to determine the statistical value of the average value obtained by the class group that was given treatment in the form of using application-based android and the class group without treatment. Then the values in the two groups are compared so that it can be seen that the average value of the two groups is the same or different significantly

\section{RESULT AND DISCUSSION}

The application-based android is used by entering a photo of the plant which will be identified, then a choice of the name of the plant to be identified will appear. Then the user chooses the name of the plant to be identified.

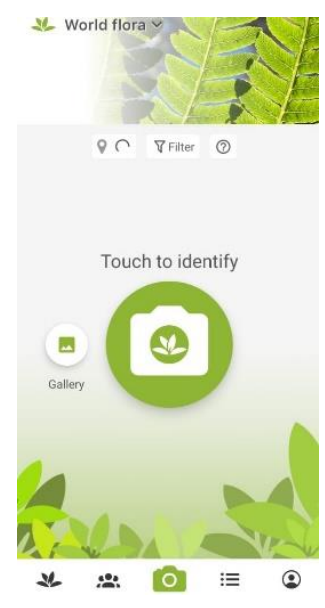

(a)

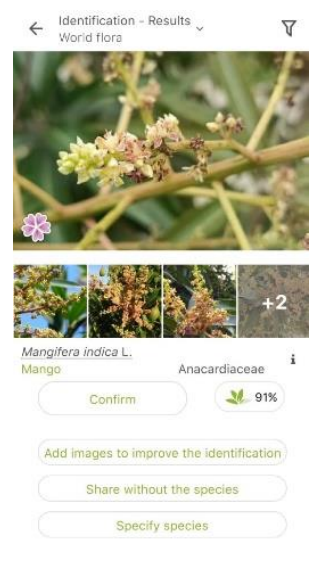

(b)
Figure 1. (a) Screen Display of Application Based Android (Plant Net), (b) The Result of Plant Identification

In this study, there are two plant identification techniques, using plant descriptions and using android-based applications. The distinguishing characteristic carried out in the control and treatment classes in this study is the effect of using android-based applications in a plant identification activity. The implementation of research activities was carried out in three stages, namely giving an initial ability test (pre-test), plant identification activities, and giving a final test (post-test). The form and number of questions given to the control class and treatment class are the same. 
The results of the pre-test and posttest aim to determine the comparison of student improvement regarding plant names. The comparison of these values is visible in the graph in Figure 1.

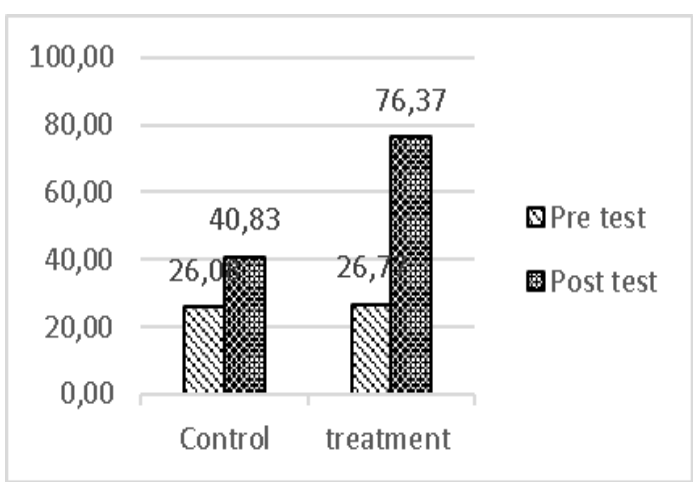

Figure 2. Comparison of Pre-test and Posttest scores

the next step, the average value of the pretest and post-test was analyzed to determine the increase in student knowledge in the control and treatment classes which is visible in table 1.

Table 1. Pre-test and Post-Test Measurement Results

\begin{tabular}{lllll}
\hline \multirow{2}{*}{ No } & \multirow{2}{*}{ class } & \multicolumn{2}{c}{ Average Score } & \multirow{2}{*}{ N- } \\
\cline { 3 - 4 } & & $\begin{array}{l}\text { Pre- } \\
\text { test }\end{array}$ & $\begin{array}{l}\text { Post- } \\
\text { Test }\end{array}$ & Gain \\
\hline 1 & control & 26,35 & 40,83 & 0,20 \\
\hline 2 & treatment & 26,77 & 76,37 & 0,68 \\
\hline
\end{tabular}

Table 1 shows that there are differences in the improvement of students' abilities in plant identification activities. The data shows that the increase in knowledge in the treatment class is higher due to the use of android-based applications by students. This is in line with the result of research (Wang, 2017) that the application of learning using mobile applications has a positive effect on students' learning attitudes. The mobile application also helps in the introduction of plants based on expert systems so that students can learn knowledge about plant genera and characteristics easily.

However, to determine the effect of using an Android-based application to identify plants, the independent-sample t- test is needed with a prerequisite test for normality and homogeneity tests on the research sample. Normality test results are visible in table 2.

Table 2. Normality Test

\begin{tabular}{lllll}
\hline \multirow{2}{*}{ No } & \multirow{2}{*}{ Class } & \multicolumn{3}{c}{ Kolmogorov- } \\
& & Smirnov \\
\cline { 3 - 5 } & & statistic & df & sig \\
\hline 1 & Control & .152 & 30 & 0,055 \\
\hline 2 & Treatment & .129 & 30 & $0,200^{*}$ \\
\hline
\end{tabular}

Based on table 2, it is visible that the data in the control class and treatment class are normally distributed. This is because the normality test value in the control class is $0.055(>0.05)$ and the treatment class is 0.200 (>0.05) so it can be concluded that the normality test is fulfilled. Next, homogeneity test analysis and independentsample t-test were conducted to determine the effect of using android-based applications for plant identification activities. Homogeneity test results and independent-sample t-test are presented in table 3 .

Table 3. The Results of Homogeneity Test and independent-sample t-test

\begin{tabular}{ll}
\hline Data & Sig. \\
\hline Levene's Test & 0,095 \\
\hline independent-sample t-test & 0.000 \\
\hline
\end{tabular}

Based on table 3, it is known that the homogeneity test using Levene's Test shows the results of $0.095(>0.05)$ this means that the sample data is homogeneous so that it can use the independent-sample t-test to determine the effect of using android-based applications in plant identification activities. Furthermore, the results in table 3 show that the value of the independent-sample t-test is $0.00(<0.05)$. This indicates that there is a significant difference in increasing student knowledge in plant identification activities in the two classes, where the experimental class shows a better improvement than the control class.

The results of the study are consistent with the impact of technological advances that the development of an automation system, including for the process of 
identifying plant species, can make it easier for observers to find out the plant species. (Wäldchen et al., 2018). In line with this, the use of mobile learning in learning can be a solution to problems in learning. In addition, android-based media can increase student participation and motivation in learned (Ardiansyah \& Nana, 2020).

The use of android-based applications can support plant identification activities. This is supported by the results of research (Imaduddin \& Tawakal, 2015) The Android operational system application is proven to be able to classify leaf types so that the application is useful as a learning tool. Other research related to the use of mobile learning states that android-based applications can be used as learning media to identify plant seeds and are suitable for use in learning. (Puspa et al., 2021).

Based on studies related to the use of android-based applications in plant identification activities, it can support students' knowledge of plant species. This is also supported by the results of research (Pujianto et al., 2020) That use of an android-based application, namely plant net, can affect learning styles. Therefore, the use of android-based applications can be applying to learning related to plant identification.

However, there are obstacles in the use of applications-based android during identification activities. For example, there are some plants whose taxonomy does not match their real names, so users must be more careful in identifying plant species.

\section{CONCLUSION}

Based on the results of data analysis, it can be concluded that the use of applications-based android affects the ability of college student to identify plants. This is proved by the comparison of student learning outcomes and the results of the independent-sample t-test which showed significant differences in the control group and the treatment class group. The data showed that the increase in knowledge in the treatment class was higher due to the use of application-based android by students. The independent-sample t-test analysis showed the sig value. $0.00(<0.05)$. It indicates that there is a significant difference in increasing student knowledge in plant identification activities in classes, where the experimental class shows a better improvement than the control class

\section{ACKNOWLEDGEMENT}

The Research of this article was funded by DIPA of Public Services Agency of Universitas Sriwijaya 2021.

SP DIPA A-023.17.2.677515/2021, on November 23, 2020. In accordance with the Rector's Degree Number 0007/ UN9/SK.LP2M.PT/2021, On April 27,2021. We Thank to Rector of Sriwijaya University and Chair of the LPPM Sriwijaya University, who have provided research funding assistance so that this research can be conducted.

\section{REFERENCES}

Ardiansyah, A. A., \& Nana. (2020). Peran Mobile Learning Sebagai Inovasi Dalam Pembelajaran Di Sekolah. Indonesian Journal of Education Research and Review, 3(1), 47-56. https://ejournal.undiksha.ac.id/index.p hp/IJERR/article/view/24245/pdf

Aring, R. D., Naharia, O., \& Lihiang, A. (2017). Pendekatan Jelajah Alam Sekitar ( Jas ) Pada Pembelajaran Biologi Topik Identifikasi Spermatophyta Terhadap Hasil Belajar Siswa Di Sma. Jurnal Sains, Matematika, \& Edukasi (JSME), 5(2), 218-228.

Bağc1, H., \& Pekșen, M. F. (2018). Investigating The Smart Phone Addictions Of Vocational School Students From Different Variables. Malaysian Online Journal of Educational Technology, 6(4), 40-52. https://doi.org/10.17220/mojet.2018.0 4.004

Fitriani, L., \& Wardianti, Y. (2014). Analisis Kemampuan Mahasiswa Mengidentifikasi Tumbuhan Paku (Pterdophyta). Ojs.StkippgriLubuklinggau.Ac.Id, 8(2), 143-151. https://ojs.stkippgrilubuklinggau.ac.id/index.php/JPP/arti cle/view/443

Imaduddin, Z., \& Tawakal, H. A. (2015). 
Aplikasi Mobile Untuk Deteksi Dan Klasifikasi Daun Secara Real Time. Jurnal Teknologi Terpadu, 1(1), 2730.

Isti, Q., Hariani, S. A., \& Murdiyah, S. (2015). Identifikasi tumbuhan berbiji (spermatophyta) di lingkungan kampus universitas jember. Jurnal Bioedukasi, XIII(2), 13-20.

Nanggala, K., \& Utara, T. (2020). BIOEDU: Jurnal Pendidikan Biologi. 5(3), 151-160.

Prasvita, D. S., \& Herdiyeni, Y. (2012). Medleaf: Aplikasi Mobile Untuk Identifikasi.

Pujianto, A. A., Degeng, I. N. S., \& Sugito, S. (2020). Pengaruh penggunaan aplikasi Plantnet dan gaya belajar terhadap hasil belajar. Jurnal Inovasi Teknologi Pendidikan, 7(1), 12-22. https://doi.org/10.21831/jitp.v7i1.313 65

Pusat Konservasi Tumbuhan. (2018). Identifikasi Tanaman. http://krbogor.lipi.go.id/id/Identifikasi -Tanaman.html

Puspa, V. R., Hidayat, T., \& Supriatno, B. (2021). Development of android-based digital determination key application (e-KeyPlant) as learning media for plant identification. Journal of Physics: Conference Series, 1806(1). https://doi.org/10.1088/17426596/1806/1/012145

Rifa, M. R., K, R. A., \& Hasanah, R. (2020). PLANTNET PADA MATA KULIAH KLASIFIKASI MAKHLUK HIDUP. VEKTOR : Jurnal Pendidikan IPA, 1, 29-37.

Suwila, M. T. (2015). Identifikasi Tumbuhan Epifit Berdasarkan Ciri Morfologi Dan Anatomi Batang Di Hutan Perhutani Sub Bkph Kedunggalar, Sonde Dan Natah. Florea: Jurnal Biologi Dan Pembelajarannya, 2(1), 47-50. https://doi.org/10.25273/florea.v2i1.4 06

Wäldchen, J., Rzanny, M., Seeland, M., \& Mäder, P. (2018). Automated plant species identification-Trends and future directions. PLoS Computational
Biology, 14(4), 1-19. https://doi.org/10.1371/journal.pcbi.10 05993

Wang, C. (2017). The research on the application of plant identification \& mobile learning app based on expert system. CSEDU 2017 - Proceedings of the 9th International Conference on Computer Supported Education, 2(5), 332-339.

https://doi.org/10.5220/000631310332 0339 